\title{
Second Times Micromole per Milliliter
}

National Cancer Institute

\section{Source}

National Cancer Institute. Second Times Micromole per Milliliter. NCI Thesaurus. Code C85806.

Seconds times micromoles per milliliter. 